\title{
Acute Toxicity Effect of The Ethanolic Extract of Watercress Herb (Nasturtium officinale R. Br.) in Mice
}

\author{
Herawaty Ginting ${ }^{1}$, Aminah Dalimunthe ${ }^{2}$, Julia Reveny ${ }^{3}$ \\ ${ }^{1}$ Department of Pharmaceutical Biology, Faculty of Pharmacy, University of Sumatera Utara, Medan, Indonesia \\ ${ }^{2}$ Department of Pharmacology, Faculty of Pharmacy, University of Sumatera Utara, Medan, Indonesia \\ ${ }^{3}$ Department of Formulation Technology, Faculty of Pharmacy, University of Sumatera Utara, Medan, Indonesia
}

\begin{abstract}
Watercress (Nasturtium officinale R. Br.) is an annual plant of the Brasicaceae family. Watercress has efficacy in the treatment of a hypo-allergenic, anti-diabetic, antioxidant, anticancer, and treatment of tuberculosis. The purpose of this research was to determine the potential for acute toxicity of ethanolic extract of watercress. This study aims to observe the histopathology liver, kidney, heart mice and to determine the LD50. Test animals used were 40 male mice and 40 female mice were divided into 8 groups. Group I as the control group were given $\mathrm{Na}-\mathrm{CMC} 0,5 \% \mathrm{~b} / \mathrm{v}$ and groups $2-8$ were given ethanol extract of watercress herb with a doses of 0,$5 ; 5 ; 50 ; 500 ; 1000 ; 2000$; and $4000 \mathrm{mg} / \mathrm{kg}$ bw. LD50 test is determined by the number of deaths in the test group during the 14 days of treatment in the form of one administration of the test materials. Histopathological results at the highest doses showed necrosis and hydropic degeneration of the liver, serosis the kidneys, and the heart inflammation with myofibril irregular heart. LD50 test demonstrated the practical test material is not toxic because no test animals died.
\end{abstract}

Keywords: acute toxicity, Nasturtium officinale R. Br., Ethanolic extract

\section{INTRODUCTION}

Biodiversity of plants native to Indonesia in the form of plants that are widely use like traditional medicine, but it has not been much done research to evaluate the safety level, while knowledge of the potential toxic effects in medicinal plants is essential to ensure the safety in uses (Soemardji, 2002).

One of those plants that were consumed as a vegetable and used as a medicine is watercress (Nasturtium officinale R. Br.) Crusiferae rate (Brasicaceae). Watercress contains alkaloids, flavonoids, saponins, terpenoids/steroids, glycosides, tannins, K, Na and $\mathrm{Ca}$ (Ginting, 2014), also contains vitamin C, vitamin A, E and $\mathrm{K}$ (Costain, 2007), folic acid, iodine, iron, protein and calcium (Gonçalves, et al., 2009). Some researches indicates that watercress may be used as an antidiabetic (Hoseini, et al., 2009), anti-allergy (Lingga, 2012), diuretics (Ginting, et al., 2014), the anti-cancer is colon cancer (Boyd, et al., 2006) and treatment of tuberculosis (Corona, et al., 2008). Test the antioxidant activity in the ethyl acetate fraction has strong $\mathrm{IC}_{50}$ value i.e., 99.73 (Lubis, et. al., 2013).

Toxicity tests using test animals as a model useful to see the reaction of biochemical, physiological and pathological human against a test preparation that can be used to prove the safety of a substance/preparation in humans, but it can give a hint of the relative toxicity and help identify toxic effects in case exposure to humans (OECD, 2001). This test can also indicate target organs that may be damaged and specific toxic effects, and provide clues about the dose should be used in testing longer ( $\mathrm{Lu}$, 1994).

Based on the above, then tested the acute toxicity of the herb watercress that has the potential to be used as a natural drug. Therefore, the use of this plant must go through a series of tests, in addition to test the efficacy should be conducted toxicity tests and histopathology of the liver, kidneys and heart.

*Corresponding author e-mail: hera_ginting@yahoo.co.id 


\section{RESEARCH METHODS}

\section{Apparatus}

Balance of electricity (Chyo JP2-6000), balance of animals (Presica Geinweigher GW1500), rotary evaporator (Heidolph vv-2000), freeze dryer (Modulyo, Edwards serial no: 3985).

\section{Materials}

The sample was taken watercress herb from Desa Semangat Gunung, Kecamatan Merdeka, Kabupaten Karo, Provinsi Sumatera Utara. All materials are chemicals analytic, 96\% ethanol, formaldehyde, except $\mathrm{Na}-\mathrm{CMC}$ (Graha Jaya), furosemide tablets (Indofarma).

\section{Simplicia Provision}

Watercress cleaned, washed with water, drained, as well as vegetables were picked and then dried in the drying cabinet $\left( \pm 40^{\circ} \mathrm{C}\right)$, after drying, blended so that becomes powder.

\section{Ethanol Extract Preparation}

A part of powder simplicia inserted into the container using 7.5 parts of $96 \%$ ethanol, macerated for 5 days, then filtering and maceration using 2.5 parts $96 \%$ ethanol for 3 days. All of the Macerat obtain were combined, then the player is done with vacuum evaporation, then drying with freeze dryer to obtain a thick extract.

\section{Animal Research}

Animals used in the study are male and female mice with a weight of $20-30 \mathrm{~g}$ of 80 mice obtained from Animal House Faculty of Pharmacy USU Medan, before the study mice were acclimatized for 7-14 days.

\section{Preparation and Animal Grouping Test}

Mice were divided into 8 treatment groups, each group consisting of 10 mice, which is 5 male mice and 5 female mice. One as a control group, a group of $2-8$ as the treatment group.

The division of the group as follows:

Group $1(\mathrm{~K})$ : controls, given the suspension of the Na-CMC $0.5 \%$ w/v

Group 2 (P1): The treatment, given EEHSA at a dose of $0.5 \mathrm{mg} / \mathrm{kg}$ bw

Group 3 (P2): The treatment, given EEHSA at a dose of $5 \mathrm{mg} / \mathrm{kg}$ bw

Group 4 (P3): The treatment, given EEHSA at a dose of $50 \mathrm{mg} / \mathrm{kg}$ bw
Group 5 (P4): The treatment, given EEHSA at a dose of $500 \mathrm{mg} / \mathrm{kg}$ bw

Group 6 (P5): The treatment, given EEHSA at a dose of $1000 \mathrm{mg} / \mathrm{kg}$ bw

Group 7 (P6): The treatment, given EEHSA at a dose of $2000 \mathrm{mg} / \mathrm{kg} \mathrm{bw}$

Group 8 (P7): The treatment, given EEHSA at a dose of $4000 \mathrm{mg} / \mathrm{kg}$ bw

\section{Administration of Test Preparation and Toxic Symptoms Observations}

Test preparation given to the test animals by orally using oral sonde with the frequency of administration once during the test period. Before the treatment, the test animals were fasted beforehand for 3-4 hours while given a drink. From each group were taken at random, occurring toxic effects were observed compared to the control. Observation time was 5, 10, 15, $30,60,120,180$ and 240 minutes. Total observation time was 4 hours, for 14 days.

Observations toxic effects that arise include the testing stage, catalepsy test, test urination, defecation test and test salivation. The test was repeated in the other mice in the same group and other groups. Observations were made continuously to determines the $\mathrm{LD}_{50}$ by looking at the number of mice that died.

\section{Observations Body Weight}

Mice were weighed every day for 14 days to see the effect of the ethanol extract of watercress herb for weight loss in mice. Weight changes are analyzed once a week.

\section{Observations Mortality Animals}

Mice were observed his death from the first day until the last day. surviving weighed and then sacrificed physically by cervical dislocation, mice were dead after the suspension of the test preparation as soon as possible surgery on the abdomen transversely and take the liver, kidneys and heart rest of the test animals were still alive until the last day to do treatment same.

\section{Weighing Organ}

Liver, kidney and heart were washed with sodium chloride, dried beforehand with absorbent paper, then weighed, while the analysis was the relative weight, i.e., absolute organ weight divided by the body weight. 


\section{Macropathology Organ}

Liver, kidney and heart were observed macroscopically the changes in color, surface and consistency of the visual organs.

\section{Histopathology Organ}

Liver, kidney and heart were washed with sodium chloride, then weighed and put into a pot containing $10 \%$ formalin, and then be making preparations histopathology in Anatomical Pathology Laboratory of the Faculty of Medicine USU.

\section{Data analysis}

Observation weight and relative organs weight were analyzed statistically using twoway analysis of variance (ANOVA) followed by Tukey's Post Hoc test with the program of Statistic Product and Service Solutions (SPSS) version 16.

\section{RESULTS AND DISCUSSION}

\section{Observations Symptoms of Toxic}

In the treatment to observes the toxic effects arising testing includes the test stage, catalepsy test, test urination, defecation test and salivation tests which showed that mice after administration EEHSA still under normal circumstances.

In the catalepsy test showed that mice in all groups are still in a state of normal mice easily reached the surface of the front foot is placed on the table pencil is moved from top to bottom. Front legs are hard driven mice showed neurological disorder that was the reaction of rigidity, tremor (trembling and convulsions visible mice induced stimulation SSP) (Pudjiastuti, 2009).

In the general urination test showed that mice after administration EEHSA still in a state of normal in all groups, the mice were still passing urine as it should be.

Namely expenditure on faeces defecation test showed that mice after administration EEHSA still in a state of normal in almost all treatment groups there was no difference.

In the test salivation ie saliva expenditure showed that mice after administration EEHSA still in normal circumstances, there are no spending saliva of mice in all groups.

\section{Observations of Body Weight}

The average weight of mice were weighed every day for 14 days and analyzed once a week can be seen in Fig. 1.

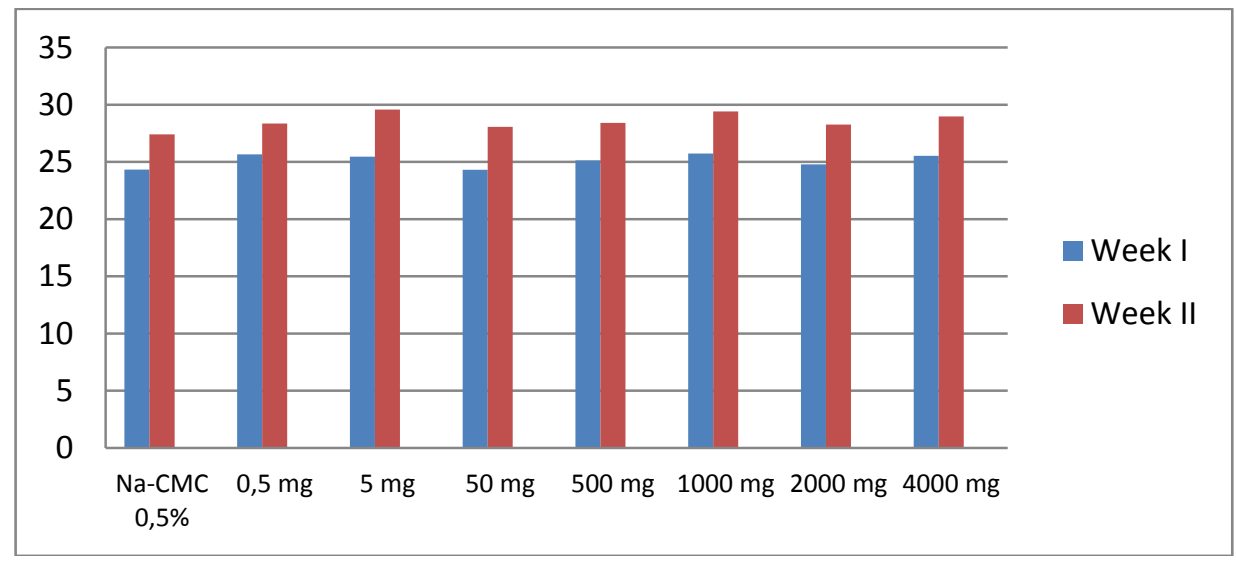

Figure I. Charts the average weight of male mice 


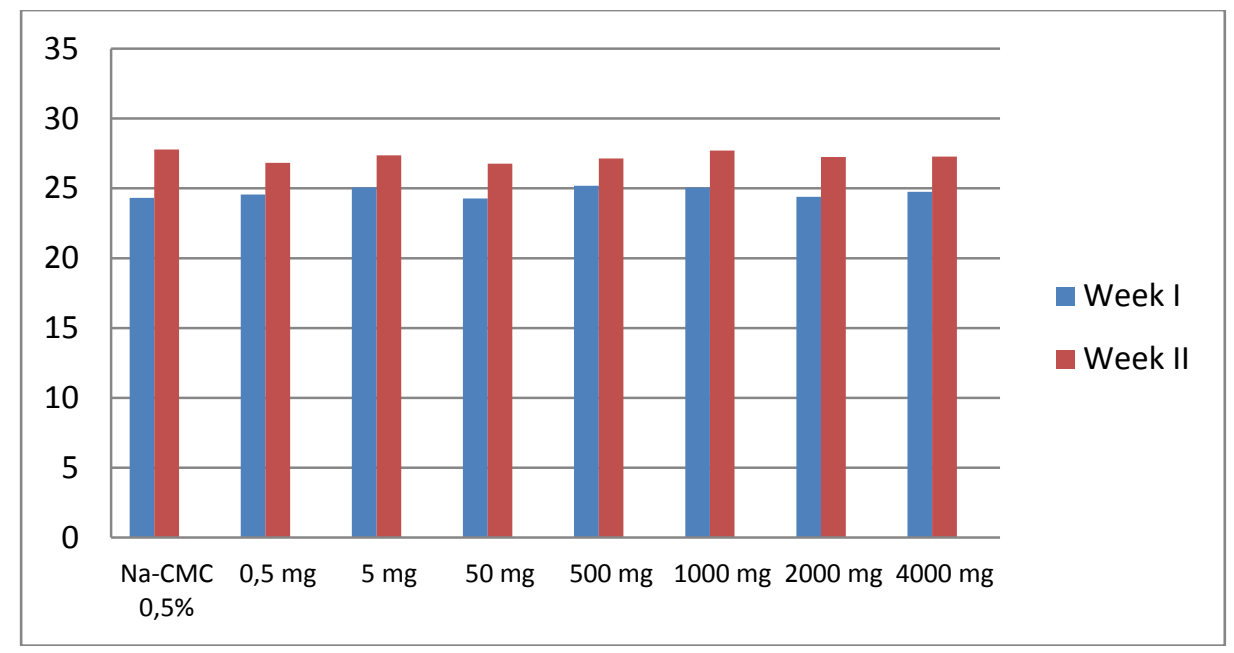

Figure 2. Charts the average weight of female mice

Results of statistical analysis using two-way ANOVA test in Fig. 1 and 2 shows that in the first week EEHSA granting no significant difference in body weight between the control mice and the test group with a significance level of $p=0.344$ ( $p>0.05$ ), At the second Week a significance level of $p=0.595 \quad(p>0.05)$. In the first week with a significance level of $p=0.148(p>0.05)$, nor was there a significant difference in body weight between male mice and female mice, but there are significant differences in the second week with a significance level of $p=0.00 \quad(p<0.05)$. Generally the body weight for an adult male mice was 20-40 g and for adult female mice of 18-35 g.

EEHSA administration of a single oral dose did not affect the body weight development of mice. Parameters that are sensitive indicators are body weight and toxic symptoms are observed every day and measured regularly (Gupta, et al., 2012). Rapid body weight loss and meaningful is usually a sign of poor health or can be caused by a lack of food and beverage consumption, disease or specific toxic signs (Wilson, et al., 2001).

\section{Observations Mortality Animals}

The number of animals death for 14 days can be seen in Table 1 .

Table 1 shows that the watercress herb extract single dose oral doses up to 4000 $\mathrm{mg} / \mathrm{kg}$ bw does not cause death in mice of all groups. According Syukur, et al., (2012), if the maximum dose does not cause the death of experimental animals, the $\mathrm{LD}_{50}$ expressed in apparent $\mathrm{LD}_{50}$ by taking the maximum dose. In this study, known as apparent $\mathrm{LD}_{50}$ is $4000 \mathrm{mg} / \mathrm{kg}$ bw. When the maximal dose there were no deaths in the test animals, then obviously these compounds are included in the criteria of "Practical Not Toxic".

\section{Results Organ Relative Weight}

Liver, kidney and heart were obtained after the animals dissected, and weighed. Relative organ weight results recorded at the end of treatment is shown in Table 2.

Table I. Observations death

\begin{tabular}{cccc}
\hline Groups of test animals & \multicolumn{2}{c}{ The number of test animals } & The number of death \\
\cline { 2 - 3 } & Male & Female & \\
\hline K & 5 & 5 & 0 \\
PI & 5 & 5 & 0 \\
P2 & 5 & 5 & 0 \\
P3 & 5 & 5 & 0 \\
P4 & 5 & 5 & 0 \\
P5 & 5 & 5 & 0 \\
\hline
\end{tabular}


Table 2. Relative organ weight results in mice

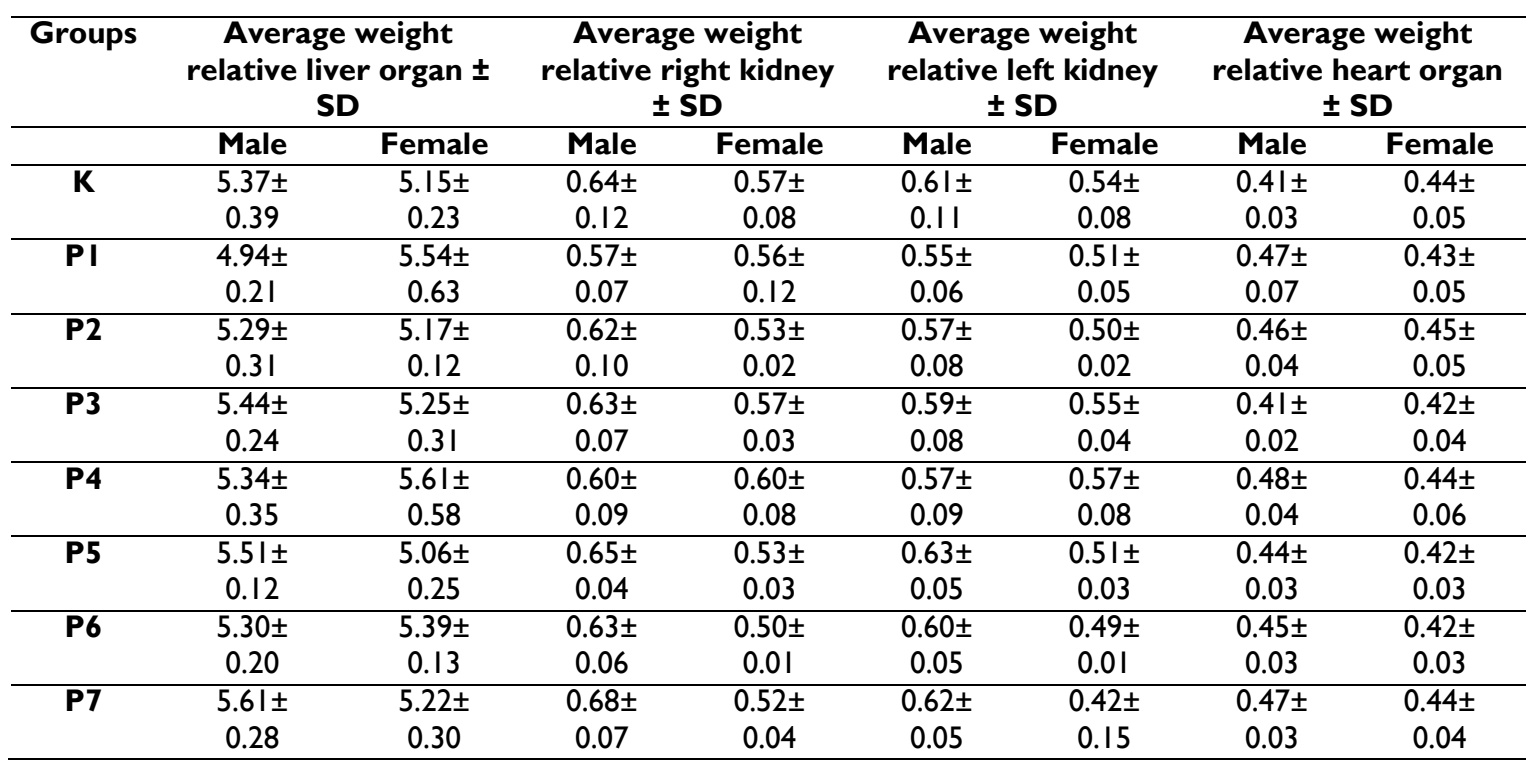

From Table 2 that were statistically analyzed using a test or two-way ANOVA showed no significant differences in relative organ weights liver, heart, kidneys right and left in male mice and female mice in all groups, thus it can be stated that the administration EEHSA single orally dose does not affect the body weight development of mice.

Examination of the liver because the liver is the center of the whole metabolism of foreign substances into the body. If the substance is toxic then it can damage the liver directly or as a consequence of metabolic changes that occur in the liver, therefore, damage to the liver can be a clue whether a substance is toxic or not (Elya, 2010).

\section{Examination Results Macropathology}

Macroscopic examination carried out by observing the changes in color, surfaces and consistency the organs of mice. Liver, kidney and heart all groups of male mice or female mice has a color of brown-red, smooth of the surfaces and supple consistency. Changing the color to one of the parameters the occurrence of toxic effects to get information about the toxicity of the test substance related to the target organs and the effects on these organs ( $\mathrm{Lu}, 1995)$.

\section{Histopathological Examination Organs of Mice}

Mice that had been dissected immediately organs. In this study no mice died, therefore the only group with the highest dose of the extract to be observed microscopically for the liver compared to controls. Liver in the control group, a dose of $2000 \mathrm{mg} / \mathrm{kg}$ bw and a dose of $4000 \mathrm{mg} / \mathrm{kg}$ bw. Histopathological preparations were made last seen under a microscope at a magnification of $400 \mathrm{X}$. The result of the damage can be seen in Table 3 and Fig. 3.

Table 3. Results of histopathological based hepatocyte damage

\begin{tabular}{cccc}
\hline Groups & Dose $(\mathbf{m g} / \mathbf{k g}$ bw) & \multicolumn{2}{c}{ The type of damage } \\
\cline { 3 - 4 } & & Hydropic Degreneration & Necrosis \\
\hline K & 0 & - & - \\
P4 & 500 & - & - \\
P5 & 1000 & - & - \\
P6 & 2000 & - & +++ \\
P7 & 2000 & +++ & moderate; $(+++)=$ severe
\end{tabular}



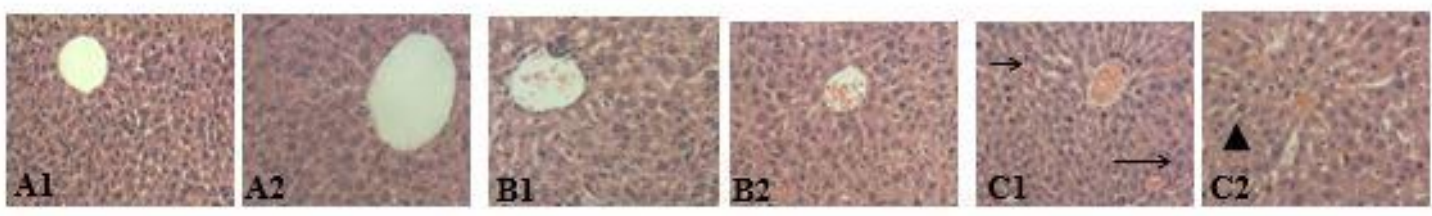

Figure 3. Histopathology liver $\mathrm{K}$ groups (AI,A2), a dose of $2000 \mathrm{mg} / \mathrm{kg}$ bw (B I,B2); a dose of $4000 \mathrm{mg} / \mathrm{kg}$ bw (CI,C2);AI,BI,CI = male mice; A2,B2,C2 = female mice; $\rightarrow$ = Karioereksis; $\rightarrow=$ Kariolisis;

$\Delta=$ hydropic degenerasition

Based on Table 3 and Fig. 3 seen in the control group, $2000 \mathrm{mg} / \mathrm{kg}$ bw look normal, hepatocyte damage that not happened, at a dose of $4000 \mathrm{mg} / \mathrm{kg} \mathrm{bw}$, hepatocyte damage that kariopiknosis, karioereksis and kariolisis. Liver damage due to toxic substances is influenced by several factors, such as the type of chemicals, the dose given and the duration of exposure to substances such as acute, subchronic or chronic.

Kidneys in mice at the control group a dose of 500, 1000, 2000 and a dose of 4000 $\mathrm{mg} / \mathrm{kg}$ bw. Histopathological preparations were made last seen under a microscope at a magnification of $10 \mathrm{x} 40$. The results of the damage can be seen in Table 4 and Fig. 4 .

From the Table 4, the provision EEHSA dose of $500 \mathrm{mg} / \mathrm{kg}$ bw and dose of $1000 \mathrm{mg} / \mathrm{kg}$ bw, there picnosis, a dose of $2000 \mathrm{mg} / \mathrm{kg}$ bw and $4000 \mathrm{mg} / \mathrm{kg} \mathrm{bw}$, necrosis this occurs due to changes in histological renal tubules (Firdaus, et al., 2012). Necrosis is characterized by color absorption by the core is reduced and the release into the lumen of the tubular cells. Bowman space narrow occurred at dose 2000 $\mathrm{mg} / \mathrm{kg}$ bw and $4000 \mathrm{mg} / \mathrm{kg}$ bw caused by the inflammation of the glomeruli, so that disrupted production and the composition of the filtrate (Mayori, et al., 2013). Serosis a cell death are severe and can spread and loss of cell nuclei or a vacancy on the tissue, where the tissue is replaced by connective tissue (Mayori, et al., 2013).

Heart organ in the control group, 1000 $\mathrm{mg} / \mathrm{kg} \mathrm{bw}, 2000 \mathrm{mg} / \mathrm{kg}$ bw, and a dose of 4000 $\mathrm{mg} / \mathrm{kg}$ bw, histopathological preparations are made and then viewed under a microscope at a magnification of $10 \mathrm{x} 40$. The results of the damage can be seen in Table 5 and Fig. 5.

Table 4. Results of histopathological based glomerular damage

\begin{tabular}{|c|c|c|c|c|c|}
\hline \multirow[t]{2}{*}{ Groups } & \multirow{2}{*}{$\begin{array}{c}\text { Dose } \\
(\mathrm{mg} / \mathrm{kg} \mathrm{bw})\end{array}$} & \multicolumn{4}{|c|}{ The type of damage } \\
\hline & & Picnosis & Necrosis & $\begin{array}{c}\text { Bowman space } \\
\text { marrowing }\end{array}$ & Serosis \\
\hline $\mathbf{K}$ & 0 & - & - & - & - \\
\hline P4 & 500 & + & - & - & - \\
\hline P5 & 1000 & + & - & - & - \\
\hline P6 & 2000 & ++ & ++ & ++ & + \\
\hline P7 & 4000 & +++ & +++ & +++ & + \\
\hline
\end{tabular}
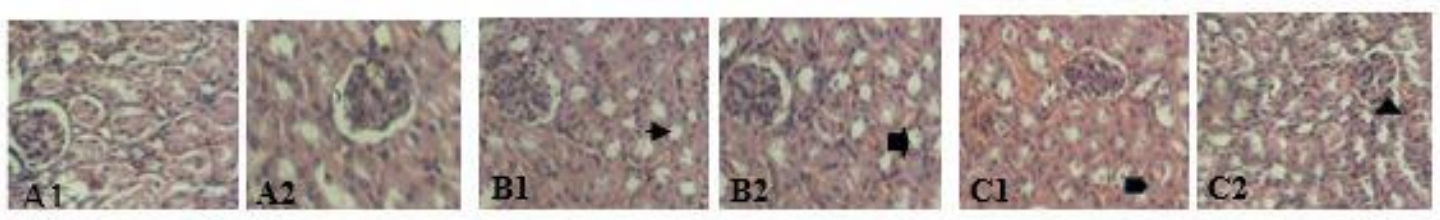

Figure 4. Histopathology kidney $\mathrm{K}$ groups (AI,A2); a dose of $2000 \mathrm{mg} / \mathrm{kg}$ bw (B I, B2); a dose of $4000 \mathrm{mg} / \mathrm{kgbw}(\mathrm{Cl}, \mathrm{C2}) ; \mathrm{AI}, \mathrm{BI}, \mathrm{Cl}=$ male mice; $\mathrm{A2}, \mathrm{B2}, \mathrm{C2}=$ female mice $\rightarrow$ = karioereksis;

= kariopiknosis;

$\Delta=$ glomerular damaged ; $=$ necrosis 
Table 5. Results of histopathological based myofibril damage

\begin{tabular}{ccccc}
\hline Groups & Dose $(\mathbf{m g} / \mathbf{k g}$ & \multicolumn{3}{c}{ The type of damage } \\
\cline { 3 - 5 } & bw) & Picnosis & Necrosis & Myofibril \\
\hline K & 0 & - & - & - \\
P5 & 1000 & + & - & + \\
P6 & 2000 & ++ & ++ & ++ \\
P7 & 4000 & ++ & +++ & +++ \\
\hline Description : $(-)=$ normal; & $(+)=$ mild; & $(++)=$ moderate; & $(+++)=$ severe
\end{tabular}
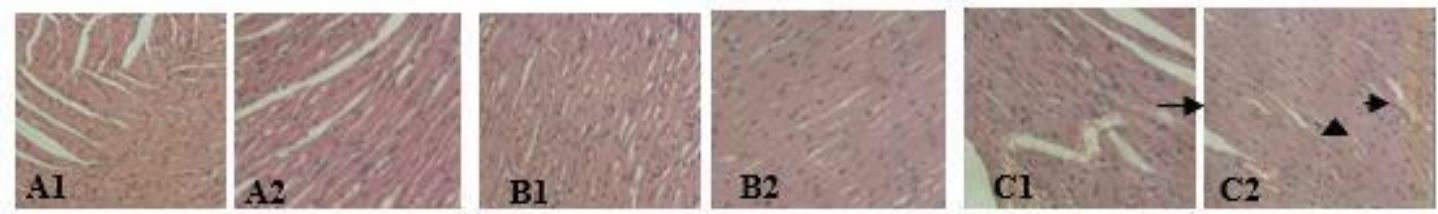

Figure 5. Histopathology of heart, $K$ groups (AI,A2), a dose of $2000 \mathrm{mg} / \mathrm{kg} \mathrm{bw} \mathrm{(BI,B2),}$ a dose of $4000 \mathrm{mg} / \mathrm{kg}$ bw $(\mathrm{Cl}, \mathrm{C2})$. $\mathrm{Al}, \mathrm{BI}, \mathrm{Cl}=$ male mice; $\mathrm{A2}, \mathrm{B2}, \mathrm{C2}$ = female mice; $\rightarrow=$ myofibril irregular;

$\rightarrow=$ karioereksis;

= kariolisis

From the table above shows that EEHSA dose of $1000 \mathrm{mg} / \mathrm{kg}$ bw occur core myosit be picnosis namely the onset of necrosis, myofibril structure damage irregular and hypertrophy characterized by thickening myosit (Widyanti, et al., 2012). Can be concluded ethanol extract of the herb watercress (Nasturtium officinale R. Br.) Dose of $0.5 \mathrm{mg} / \mathrm{kg} \mathrm{bw}, 5 \mathrm{mg} / \mathrm{kg}$ bw, 50 $\mathrm{mg} / \mathrm{kg}$ bw, $500 \mathrm{mg} / \mathrm{kg}$ bw, $1000 \mathrm{mg} / \mathrm{kg}$ bw, $2000 \mathrm{mg} / \mathrm{kg}$ bw and $4000 \mathrm{mg} / \mathrm{kg}$ bw.

At a dose of $2000 \mathrm{mg} / \mathrm{kg}$ bw, picnosis, and a dose of $4000 \mathrm{mg} / \mathrm{kg}$ bw increased picnosis formation and inflammation of the heart muscle and myofibril also increasingly irregular. Not Toxic". But microscopically at a dose of $4000 \mathrm{mg} / \mathrm{kg}$ bw can cause damage to the liver cells form hydropic degeneration and necrosis of the liver, cause glomerular damaged in kidney, cause picnosis and myofibril irregular of the heart.

\section{CONCLUSION}

Based on research that has been done, it did not show symptoms of toxic 50 $\mathrm{mg} / \mathrm{kg}$ bw, $500 \mathrm{mg} / \mathrm{kg}$ bw, $1000 \mathrm{mg} / \mathrm{kg}$ substances in the test stage, test catalepsy, test urination, test defecation, test salivation and the absence of the death of mice so that the ethanol extract of the herb watercress included in criteria "Practical Not Toxic". But microscopically at a dose of $4000 \mathrm{mg} / \mathrm{kg}$ bw can cause damage to the liver cells form hydropic degeneration and necrosis of the liver, cause glomerular damaged in kidney, cause picnosis and myofibril irregular of the heart.

\section{REFERENCES}

Anggraini, D.R., 2008, Gambaran Makroskopik dan Mikroskopik Hati dan Ginjal Mencit Akibat Pemberian Plumbum Asetat, Thesis, Sekolah Pascasarjana Universitas Sumatera Utara, Medan.

Boyd LA, McCann MJ, Hashim Y, Bennett RN, Gill Cl, Rowland IR.. 2006, Assessment of the Anti-Genotoxic, AntiProliferative, and Anti-Metastatic Potential of Crude Watercress Extract in Human Colon Cancer Cells, Nutr. Cancer, 55(2), 232-24I.

Camacho-Corona Mdel R, Ramírez-Cabrera MA, Santiago OG, Garza-González E, Palacios Ide P, Luna-Herrera J, 2008, Activity Against Drug ResistantTuberculosis Strains of Plants Used in Mexican Traditional Medicine to Treat Tuberculosis and Other Respiratory Diseases, Phytother. Res., 22(I), 82-85.

Costain, L., 2007, Watercress the Original Superfood, http://watercress.co.uk/wpcontent/upl oads/2012/0I/superfoodl.pdf, Cited March, 52015. 
Ditjen POM, 1979, Farmakope Indonesia, 3rd Edition, Jakarta: Departemen Kesehatan Republik Indonesia.

Elya, B., Juheini, A. dan Emiyanah, 2010, Toksisitas Akut Daun Justicia Gendarussa Burm, Makara, Sains, I 4(2), I 29- I 34.

Ginting, H., Aminah, F. and Dalimunthe, A., 2014, Penelitian Hibah Bersaing: Ekstrak Etanol Selada air (Nasturtium officinale $R$. Br.) Sebagai Bahan Baku Pembuatan Tablet Diuretika, Medan: Universitas Sumatera Utara.

Gonçalves, E.M., Cruz, R.M.S., Abreu, M., Brandao, T.R.S. and Silva, C.L.M., 2009, Biochemical and Colour of Watercress (Nasturtium officinale R.Br) during Freezing and Frozen Storage, J. Food Eng., 93(I), 32-39.

Gupta, D. and Bhardwaj, S., 2012, Study of Acute, Subacute and Chronic Toxicity Test, Int. J. Advanced Res. in Pharm. and Bio Sci., I (2), I03-I I 4.

Hoseini, H.F., 2009, The Effect of Nasturtium officinale on Blood Glucose Level in Diabetic Rats, Pharmacologyonline, 3, 866-87I.

Lingga, L., 2012, The Healing Power of Antioxidant, Jakarta: PT Elex Media Komputindo.

Lu, F.C., 1994, Toksikologi Dasar: Asas, Organ, Sasaran, dan Penilaian Risiko, In: Nugroho, E., Bustami, Z.S. and Darmansjah, I., translator, 1994, Toksikologi Dasar: Asas, Organ, Sasaran, dan Penilaian Risiko, 2nd Edition, Jakarta: Universitas Indonesia Press.

Muntiha, M., 200I, Teknik Pembuatan Preparat Histopatologi dari Jaringan Hewan Dengan Pewarnaan Hematoksilin dan Eosin (H\&E), Temu Teknis Fungsional Non Peneliti, n.v, I56-I63.
National Toxicology Program, 2011, OECD Guidelines for Testing Chemicals 423, Durham: US Department of Health and Human Service.

Praptiwi, Wulansari, D. and Chairul, 2010, Efek Toksisitas Ekstrak Pegagan (Centella asiata Linn.) Pada Organ dan Jaringan Mencit (Mus musculus), Majalah Farmasi Indonesia, 2 I (I), 40-47.

Priyanto, 2009, Toksikologi Mekanisme, Terapi Antidotum, dan Penilaian Resiko, Jakarta: Lembaga Studi dan Konsultasi Farmakologi Indonesia (LESKONFI).

Pudjiastuti. and Yun, A.S., 2009, Uji Gelagat dan Uji analgesik Ekstrak Etanol Daun Kembang Sungsang (Gloriosa superba L) pada Hewan Coba, Jakarta: Puslitbag Biomedis dan Farmasi.

Smith, E.S., 2002, Terapi Sayuran. Cetakan Pertama, Jakarta: Prestasi Pustaka.

Soemardji, A. A., Endang, K., and Cucu, A., 2002, Toksisitas Akut dan Penentuan DL50 Oral Ekstrak Air Daun Gandarusa (Justicia gendarussa Burm. F.) pada Mencit Swiss Webster, Jurnal Matematika dan Sains, 7(2), 57-62.

Sukandar, E., 2006, Nefrologi Klinik, 3rd Edition, Bandung: Fakultas Kedokteran UNPAD.

Syukur, R., Elly, W., Usmar. and Rina, M., 2012, Uji Toksisitas Akut Sirup Kasumba Turate Pada Tikus Wistar Sebagai Prototipe Sediaan Fitofarmaka: Penentuan LD50, Majalah Farmasi dan Farmakologi, I6(3), |43-I46.

Wilson N., Jerry F. H. and Johnnie R. H, 200I, Short-term, Subchronic and Chronic Toxicology Studies. Dalam:Taylor \& Francis, penyunting, Principles and Methods of Toxicology, 4th Edition, Philadelphia: Lippincot Williams andWilkins. 